Scientific Journal of October 6 University

ISSN (Print): 2314-8640

ISSN (Electronic): 2356-8119

Published by October 6 University (C) All Rights Reserved

Available online at: http:// sjou.journals.ekb.eg
Citation: Hassan et al., Biosynthesis of Zinc Oxide Nanorods Using Bacterial Cellulose as a Biotemplate Sci. J. of Oct. 6 Univ.3(2), 21-27.

Copyright: (C) 2016 Hassan et al. This is an open-access article distributed under the terms of the Creative Commons Attribution License, which permits unrestricted use, distribution, and reproduction in any medium, provided the original author and source are credited.

Original Article

\title{
Biosynthesis of Znic oxide nanorods s Using Bacterial Cellulose as a Biotemplate
}

\author{
Amr Hassan $^{1}$, Noha Sorour ${ }^{1}$, Ashraf El-Baz ${ }^{1}$ and Yousseria shetia ${ }^{2}$ \\ ${ }^{1}$ Department of Industrial Biotechnology, Genetic Engineering and Biotechnology Research Institute (GEBRI), \\ University of Sadat City, Sadat City, Egypt \\ ${ }^{2}$ Department of Microbiology, Faculty of Science, Ain Shams University, Cairo, Egypt
}

Received: 3-04-2016 Revised: 10-04-2016 / Accepted: 20-5-2016

\begin{abstract}
Fabrication of znic oxide nanorods s by using sol- gel technique by Bacterial cellulose Robbins mediated static fermentation of Komagataeibacter Xyliunus The characterizations of znic oxide nanorods using A Fourier transform- infrared spectrum (FTIR) confirmed the presence of ZN-O group while XRD provide the crystalline of znic oxide nanorods s, TEM and SEM confirmed the shape of zinc nanorod in rod shape and the diameter in an average of $214 \mathrm{~nm}$. The thermal analysis of znic oxide nanorods $\mathrm{s}$ has been studied by Thermo gravimetric analysis (TGA) show that the bacterial cellulose has been pyrolysis at $643^{\circ} \mathrm{C}$ by thermal treatment. Finally, we success to fabricated of $\mathrm{ZnO}$ nanorods using ecofriendly method mediated Bacterial cellulose Robbins as a biomaterial to control the shape $\mathrm{ZnO}$ NRs.
\end{abstract}

Key Words: Znic oxide nanorods, bacterial cellulose and, sol - gel technique.

\section{Introduction}

Nanotechnology is an advanced technology that contributes with sophisticated technology in many disciplines as environmental, medical science, mechanical and electronic engineering, biology, telecommunication teleology and Metallurgy (Chen et al ., 2007 ;2013). It has become a hot spot of research in modern material science (Sirelkhatim etal., 2015). Nanotechnology allows to design and control of size, dimension and morphology of material at nanoscale $\left(\begin{array}{lll}0 & -100 & \mathrm{~nm}\end{array}\right)$ (Wang et al.,2008) . In last decades, there is more interest with one (1D) nanomaterial due to wide applications (Duan et at., 2001; Pan et al., 2001; Whang et al., 2003). Zinc oxide ( $\mathrm{ZnO})$ is considered as semiconducting material and piezoelectric material with a direct wide band gap of $3.37 \mathrm{eV}$ and has a large excitation binding energy of $60 \mathrm{meV}$ at room temperature (Ozgur et al., 2005; Look, et al ., 2001). Zinc oxide nanoparticle ( $\mathrm{ZnO}$ NPs) often used as a highly functional metallic nanoparticle (Wang et al.,). Zinc oxide nanoparticle (ZnO NPs) often used as a highly functional metallic nanoparticle .,2014). ZnO nanoparticles have various applications in electronic, optoelectronic, electrochemical and electromechanical devices (Heo et al ., 2004; Yi et al .,2005; Huang et al ., 2001), Such as ultraviolet (UV) laser
(Wang et al.,2008), light- emitting diodes (Parke et al ., 2004), field emission devices

(Wang et al ., 2006), high performance nanosensor (Wei et al ., 2009; Yeh et al., 2009), solar cells (Law et al ., 2005; Levy-Clement et al., 2005 ), and piezoelectric nanogenerators (Wang et al ., 2006; Wei et al ., 2010). ZnO nanoparticle contribute in many applications including pharmaceutical, cosmetology, catalysis, industrial and biomedical science (Premanathan et al., 2011; Koipaei et al., 2016). One-dimensional metal-oxide nanostructures have been interested in; due their unique electronic and optical properties. One dimension nanostructure has various shapes such as nanotube (Berry et al ., 2005), nanowires (NWs) nanorod (Miao et al ., 2004) and nanofiber (Berry et al .2004). One-dimensional (1D) semiconductor nanostructures have been of intense interest in both academic research and industrial applications because of their potential as building blocks for other structures (Zhang et al., 2012). Nanostructured $\mathrm{ZnO}$ has a high surface area, good biocompatibility, and chemical stability, nontoxic and has a high isoelectric point (IEP) of about 9.5. Therefore, $\mathrm{ZnO}$ nanostructure is suitable for absorption of protein with low iso-electric oil point (IEP) due to protein immobilization that depends on the electrostatic interaction. BCF is secreted 
from Gluconactobacter (Acetobacter xylinum) which has unique properties, such as large surface area, high tensile strength, abundance, high water retention capacity, high crystallinity fine fiber network, biocompatibility, relative simple and low cost ${ }^{24}$. BCF pellicles have ribbon-shape ultrafine nano-fiber with width less than (100nm) (Svenssona et al., 2008; Ross et al., 1991; Ma.et al ., 2010; Klemm et al ., 2001).

In the presented work, bacterial cellulose was used as biotemplate to synthesiz $\mathrm{ZnO}$ nanorod using the sol-gel technique. Synthesized $\mathrm{ZnO}$ nanorods were structurally characterized using SEM, TEM, FTIR and XRD analyses.

\section{Material and methods}

\section{Chemicals}

Zinc acetate hydrate $\left(\mathrm{Zn}(\mathrm{CH} 3 \mathrm{COO})_{2} \cdot 2 \mathrm{H}_{2} \mathrm{O}\right)$ were obtained from oxford (India), $\mathrm{NaCl}$, yeast extract , glucose , $\mathrm{Na}_{2} \mathrm{HPO}_{4}, \mathrm{NaOH}$, Citric acid were supplied from SAS chemical CO, (MUMBAI). All solutions were prepared using double deionized distilled water.

Biosynthesis and purification of the Bacterial Cellulose

Komagataeibacter Xyliunus (ATCC 10245) was incubated statically in Hestrin and Schramm (HS) medium(Schramm et al ., 1954) containing 20g/L D-glucose, $5 \mathrm{~g} / \mathrm{L}$ yeast extract, $5 \mathrm{~g} / \mathrm{L}$ peptone, and $2.7 \mathrm{~g} / \mathrm{L} \mathrm{Na}_{2} \mathrm{HPO}_{4}$ and $1.15 \mathrm{~g} / \mathrm{L}$ citric acid in deionized water (DI). The $\mathrm{pH}$ of the medium was adjusted to $6.0-6.2$ using $10 \% \mathrm{NaOH}$ or $0.1 \mathrm{M} \mathrm{HCl}$. Three days old starter culture was disturbed with the ratio $1: 10$ in $500 \mathrm{~mL}$ flask containing $\mathrm{HS}$ medium, then incubated at $30{ }^{\circ} \mathrm{C}$ for 5-7 days. The Bacterial Cellulose Ribbons (BC) were harvested after 5 days. Harvested BC Ribbons were boiled in deionized water (DI) at $700 \mathrm{C}$ for 3 hours, then in $2 \% \mathrm{NaOH}$ followed by deionized distilled water and dried at $70{ }^{\circ} \mathrm{C}$ prior to use.

\section{Synthesis of ZnO Nanorods}

$\mathrm{ZnO}$ nanorod was synthesized using sol-gel method. $1.5 \mathrm{~g}$ of $\mathrm{Zn}(\mathrm{CH} 3 \mathrm{COO})_{2} .2 \mathrm{H}_{2} \mathrm{O}$ was dissolved in $15 \mathrm{~mL}$ of ultrapure water (milli -Q water, USA) (18 M $\Omega$ ) containing (100 mg/ml-1) of $\mathrm{BCF}$, stirred for $30 \mathrm{~min}$. and heated at $60 \mathrm{oC}$ for $2 \mathrm{hrs}$. Then, placed in the oven for calcination at $700{ }^{\circ} \mathrm{C}$; where the temperature increases gradually with the rate of $4^{\circ} \mathrm{C}$ per minute for 3 hours; annealing the $\mathrm{ZnO}$ nanorods gradually; and then further characterized.

\section{ZnO Nanorods Characterization}

The crystalline nature and grain size of $\mathrm{ZnO}$ nanorods was carried out by $\mathrm{X}$ - ray diffraction (XRD) pattern at 25-280C with a D8 Advance X ray diffractometer (Bruker - Germany) with a nickel (Ni) filtered using $\mathrm{CuK} \alpha(\lambda=1.54184 \mathrm{~A} 0)$ radiations as an X-ray source. A Fourier transforminfrared spectrum (FTIR) of sample is registered using Nicolet 6700 (Thermo scientific-USA). The thermal analysis was measured using Thermo gravimetric analysis (TGA) TGA -50 (Shimadzu, Japan) Morphology and size of $\mathrm{ZnO}$ nanoparticle were examined by Scanning Electron Microscope (SEM, JSM- 690, JEOL, Inc., Tokyo, Japan) and Field Emission Transmission Electron Microscopy (FETEM, JSM- 2100F, JEOL Inc.) at an accelerating voltage of $15 \mathrm{Kv}$ and $200 \mathrm{Kv}$.

\section{Results and Discussion}

\section{Structure characterization of the biosynthesized $\mathrm{BC}$ and $\mathrm{ZnO}$ nanorods}

\section{FT-IR spectroscopy}

Result obtained in Figure (1) showed that the FTIR spectrum of $\mathrm{BC}$ have a strong absorption peak at $3396.1 \mathrm{~cm}^{-1}$ representing the $\mathrm{OH}$ group. Broad band of $3394 \mathrm{~cm}^{-1}$ indicates the presence of more hydrogen bonding pattern. Our results correlate with the findings of (Slusaraka et al ., 2008) who indicated that Acetobacter Xylinum grown in HS medium produced cellulose showing IR spectrum in the region of $3400 \mathrm{~cm}-1$. The strong absorption peak at $1638 \mathrm{~cm}-1$ confirms the presence of carboxylic acid group $(\mathrm{COOH})$ in the cellulose structure. The bands at $715 \mathrm{~cm}-1$ show the possibilities $\mathrm{C}-\mathrm{O}-\mathrm{C}$ functionalities present in the BC. According to Jung et al. (Jung et al .,2010) who reported that the IR spectrum of BC produced in molasses medium is observed in the region of $3240 \mathrm{~cm}-1$, attributing to the presence of more quantities of cellulose I $\alpha$. Our results (Figure 1A) indicated that the transmittance peak near to 3240 $\mathrm{cm}-1$ is achieved, indicating that cellulose $\mathrm{I} \alpha$ is abundantly present in the BC produced in $\mathrm{HS}$ medium. Figure (2) showed the FT-IR spectra of $\mathrm{ZnO}$ nanostructure prepared using $\mathrm{BC}$ as bio template by sol-gel method. There is a strong peak at $493.5 \mathrm{~cm}-1$ indicated $\mathrm{ZnO}$ nanoparticle formation and weak broad peak at $3438.2 \mathrm{~cm}-1$ corresponding to the hydroxyl group. The result obtained (Figure 2) indicated that the hydroxyl groups have a strong interaction with $\mathrm{Zn}^{2+}$ ( $\mathrm{Li}$ et al., 2009). While, the disappearance of peak at $1638 \mathrm{~cm}-1$ as a result of thermal treatment and BC pyrolysis Overall, results confirmed the formation of $\mathrm{ZnO}$ nanorod shaped (Que et al ., 2005) .

\section{XRD structure characterization of $\mathrm{ZnO}$ nanorod}

Results obtained in Figure (3) showed X-ray Diffraction (XRD) patterns of $\mathrm{ZnO}$ nanorod. The peaks at $2 \theta=31.746,34.395,36.226,47.526$, $56.549,62.832,67.893$ and 69.028 were assigned to (100), (002), (101), (110), (103), (200), (112) and (201) of $\mathrm{ZnO}$ nanorod All peaks were indicated polycrystalline Wurtzite structure (Zincite, JCPDS 
no.: 79-2205). No characteristic peaks of any impurities were detected indicating the quality of the prepared $\mathrm{ZnO}$ nanorod. The XRD pattern is identical to the hexagonal phase with Wurtzite structure with space group $(\mathrm{C} 6 \mathrm{~V}=\mathrm{P} 63 \mathrm{mc})$ and unit cell parameter $\mathrm{a}=\mathrm{b}=\mathrm{c}=3.248 \AA$ and $\mathrm{c}=5.2 \AA \mathrm{The}$ average crystal sizes of $\mathrm{ZnO}$ nanorod obtained with calcinating temperature at $700{ }^{\circ} \mathrm{C}$ for $180 \mathrm{~min}$. The average crystallite size (d) of $\mathrm{ZnO}$ nanowire was estimated by Scherer's equation (Patterson et al., 1939).

\section{$d=k \lambda \beta \cos \theta \theta$}

Where $\mathrm{k}=0.9$ is the shape factor, $\beta$ is the measured FWHM (Full Width at Half Maximum), $\theta$ is the Bragg angle of the peak, $\lambda$ is the XRD wavelength. The average crystal size of $\mathrm{ZnO}$ nanowire was found to be $214 \mathrm{~nm}$ (Figure 2).

\section{Thermal properties of $\mathrm{ZnO}$ nanorods}

Figure (4) showed the Thermo Gravimetric Analysis (TGA) of synthesized $\mathrm{ZnO}$ using $\mathrm{BC}$ nanofiber biotemplate. Results obtained in Fig. (3) explained the reaction of Zinc acetate dehydrate during the pyrolysis process of the $\mathrm{BC}$ ribbons. Three weight losses were observed during the thermal degradation curve of BC. The first steps showed a weight loss between $61 \mathrm{oC}$ and $287 \mathrm{oC}$, where physically adsorbed zinc ions with hydrogen bonded linked to water molecules were lost at the first stage due to the dehydration of $\mathrm{BC}$ and Zinc acetate dehydrate. The second stage has a weight loss that can be explained by the decomposition of zinc acetate. The third stage occurs between $300 \mathrm{C}^{0}$ and $530 \mathrm{C}^{0}$ with calcination of the $\mathrm{ZnO}$ nanorod. The exothermic peak at $643 \mathrm{C}^{0}$ could be attributed to the termination of the pyrolysis process and preliminary crystallization of the $\mathrm{ZnO}$ nanorod. Thus, overall, the fabrication process of $\mathrm{ZnO}$ nanorods has two steps: one is the adsorption of zinc ions onto the $\mathrm{BC}$ fibers and the second is the removal of $\mathrm{BC}$ templates at high temperature (700 ${ }^{\mathrm{O}} \mathrm{C}$ under atmospheric air (Su et al., 2009).

\section{Morphologylogical studies of $\mathrm{ZnO}$ nanorods}

SEM image obtained in Figure (5) showed the bacterial cellulose (BC) after suspension with ultrapure water for $10 \mathrm{~min}$. BC have ribbons shape and were produced from Komagataeibacter Xyliunus in the static fermenation culture. Micrographs of thread like cellulosic microfibrils appears and the bacterial cells entangled in its fibrils are tightly packed with conferred morphological feautres similar to that of pure micrphological cellulose. SEM of $\mathrm{ZnO}$ nanorods presented in Figure (6) indicated that there is no impurities on the surface it is is smooth. Figure (7) showed the TEM image that confirms the structure of $\mathrm{BC}$ ribbons, while in Figure (8), TEM analysis of $\mathrm{ZnO}$ nanorod confirmed its rod shape with a diameter of $214 \mathrm{~nm}$.

\section{Conclusion and recommendation}

A facile approach has been proposed to prepare $\mathrm{ZnO}$ nanorods with ecofriendly green technology using the sol-gel technique; which is considered as the best method to control the dimension, as well as, the shape of nanomaterial. The advantage of BC as a matrix network can be used as good biomaterial template to prepare 1-D nanostructure. This approach provides an environment-friendly, simple and efficient technique for the preparation of well-structured shaped of $\mathrm{ZnO}$ nanorod. Moreover, this method could be used to prepare other nanoscale metal oxide from the thermal decomposition process. In the future, we recommend proceeding further using the advantages of using $\mathrm{ZnO}$ nanorod in the field of cancer therapy due to its reactive oxygen species or as a biosensor due its electric conduction.

Conflict of Interest Statement: The author declares no conflicts of interest.

\section{Acknowledgements}

This work was supported by Genetic Engineering and Biotechnology Research Institute (GEBRI) Sadat City University. We are grateful to Professor Ashraf El-Baz and Noha Sorour for providing the material used in this work, And professor Yousseria shetia for providing the facilities. 
Fig(1) the FT-IR of bacterial cellulose using static culture of Komagataeibacter Xyliunus.

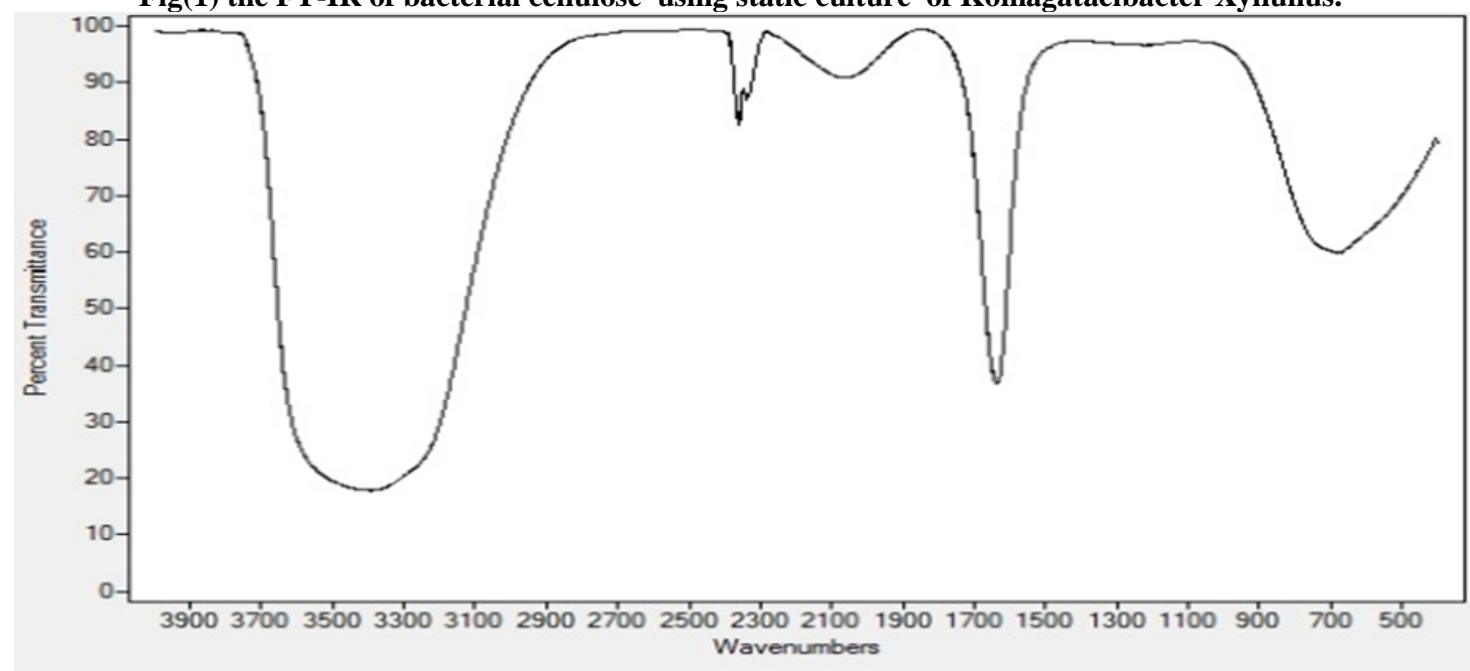

Fig (2) the FT-IR spectra of $\mathrm{ZnO}$ after synthesize by sol gel technique

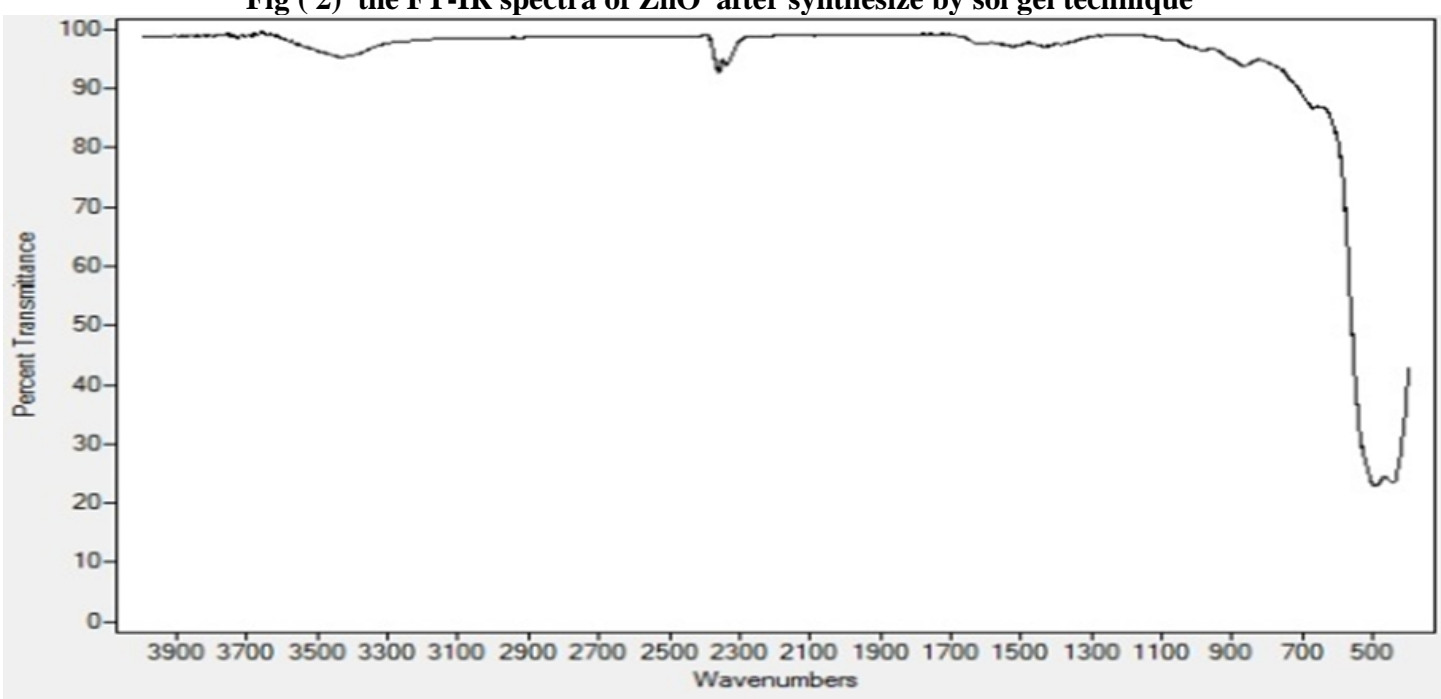

Fig (3) shows XRD patterns of $\mathrm{ZnO}$ nanorod

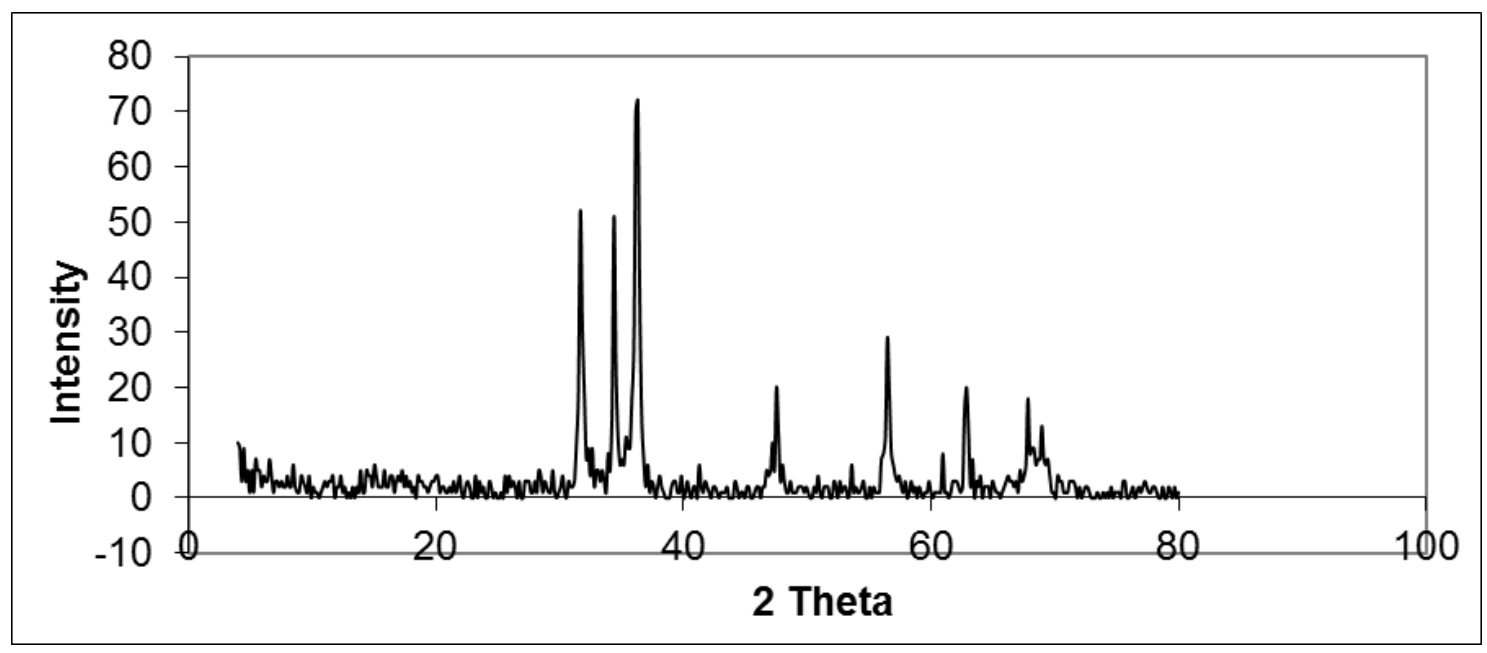


Fig (4) shows the curves of Thermogravimetric analysis (TGA) $\mathrm{ZnO} / \mathrm{BC}$ nanofiber

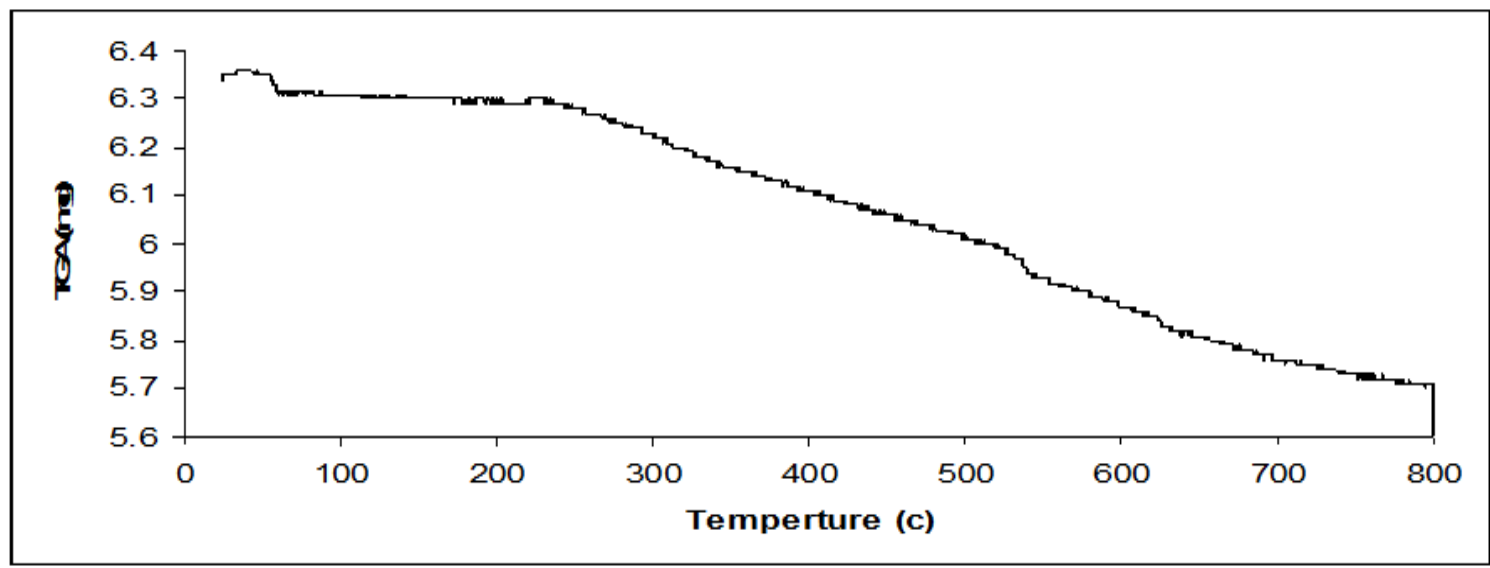

Fig (5) the Scanning electron microscope of bacterial cellulose

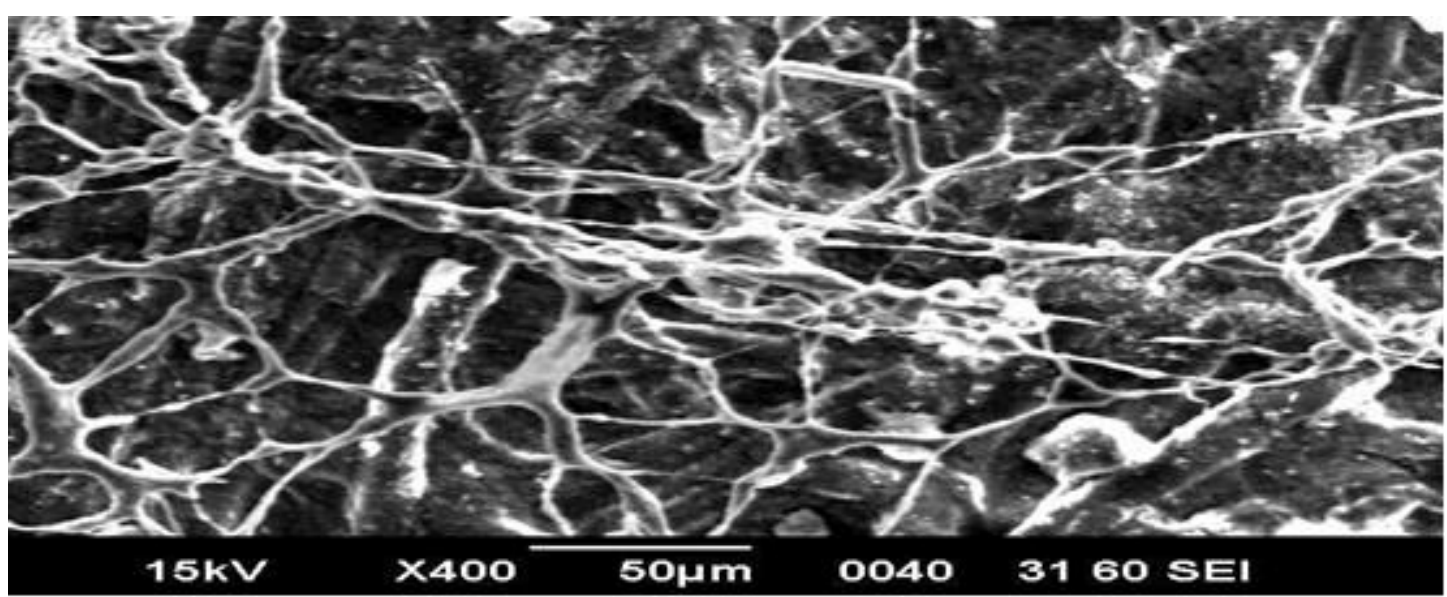

Fig (6) the Scanning electron microscope of $\mathrm{ZnO}$ nanorod

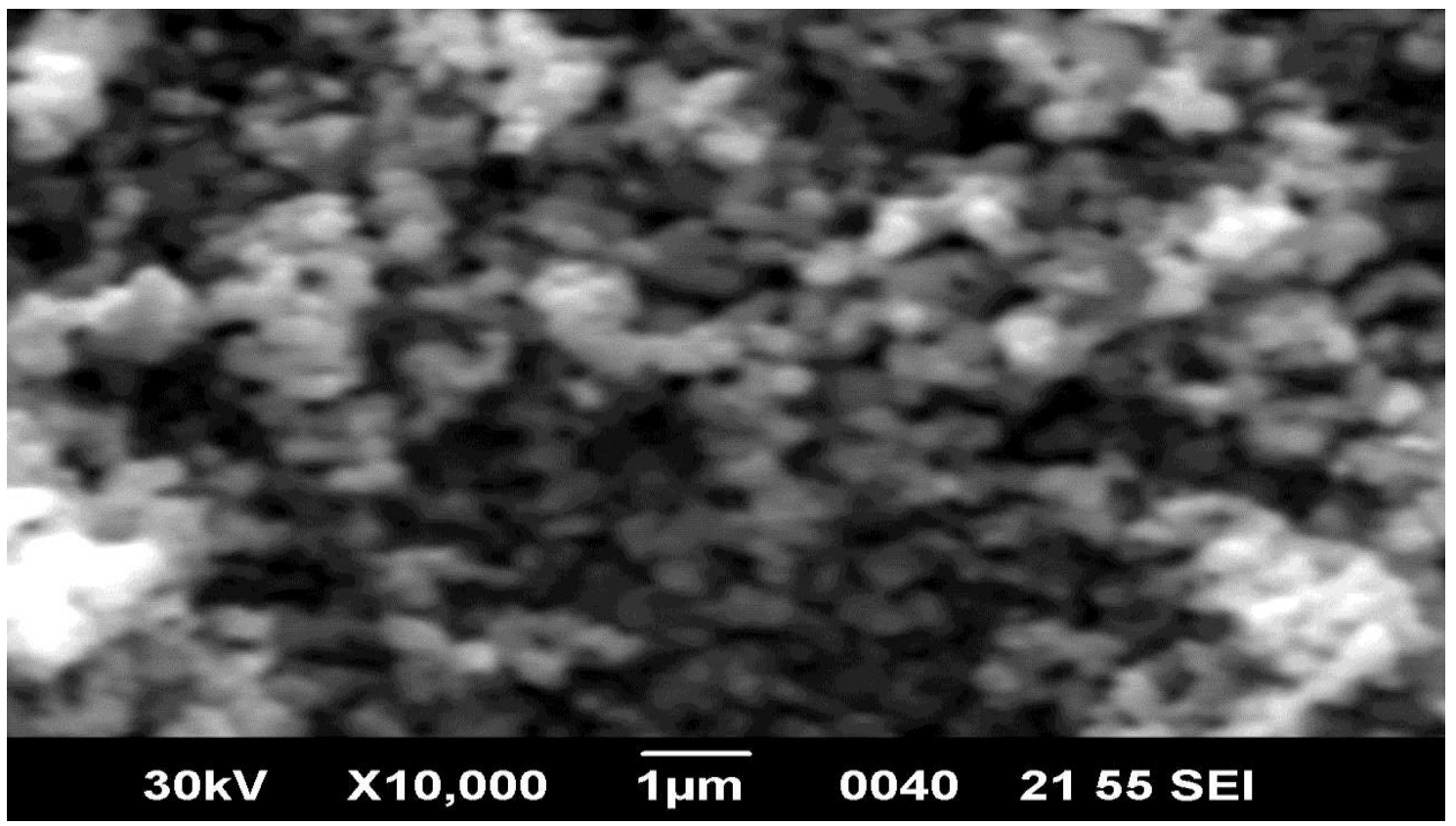


Fig(8) The transmission electron of bacterial cellulose

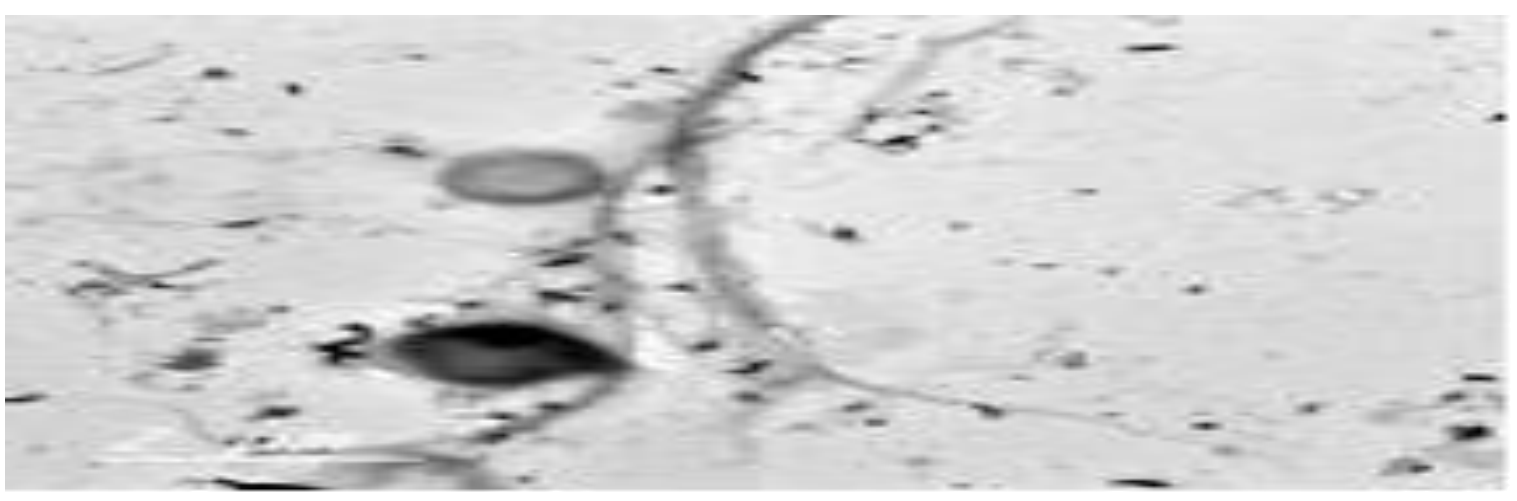

Fig(8) The transmission electron microscope of znic oxide nanorods

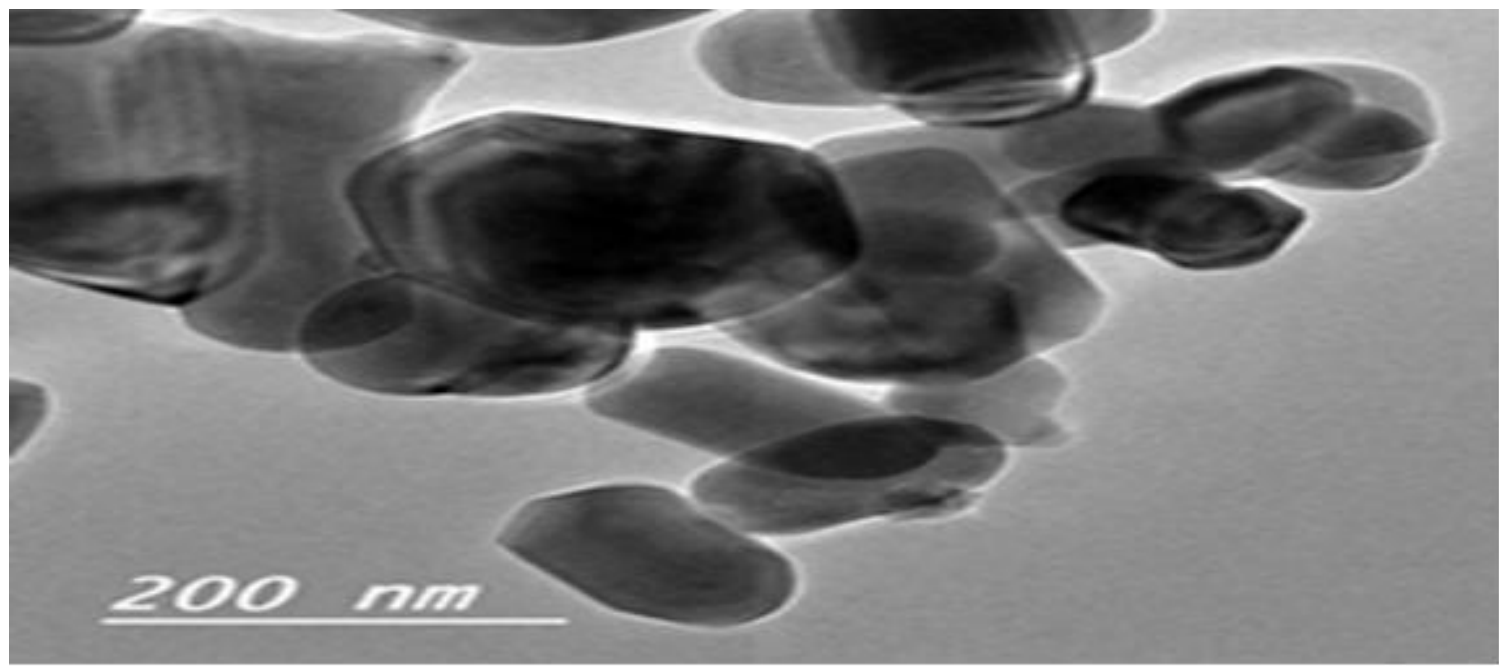

\section{References}

Berry V, Gole.S, Kundu S, Murphy CJ, Saraf RF. (2005). Deposition of CTAB-terminated nanorods on bacteria to form highly conducting hybrid systems. J. Am. Chem. Soc. 127: 176184.

Berry V, Rangaswamy S, Saraf RF. (2004). Highly selective, electrically conductive monolayer of nanoparticles on live bacteria. Nano Lett., 4: 939-942.

Chen X, Mao SS.(2007). Titanium dioxide nanomaterials: synthesis, properties, modifications, and applications. Chem Rev;,107:291-298.

Chen X ,Tang Y, Jiang Z, Xing C, Li A, Kanhere PD, Zhang Y, Sum C, Dong Z, Chen Z. (2013). Efficient $\mathrm{Ag} @ \mathrm{AgCl}$ Cubic Cages Photocatalyst Profited from Ultrafast Plasmon-induced Electron Transfer Process" Adv. Funct. Mater 23: 2932-2940.

Duan X, HuangY, Cui Y, Wang J, Lieber CM (2001). Indium phosphide nanowires as building blocks for nanoscale electronic and optoelectronic devices.Nature, 409: 66-74.

Heo YW, Norton D, Tien LC, Kwon Y, Kang BS, Ren F, Pearton S, LaRoche R. (2004). $\mathrm{ZnO}$ nanowire growth and devices. Mat. Sci. Eng. R, 47: 147-153.

Huang M H, Mao S, Feick H, Yan HQ, Wu YY, Kind H, Weber E, Russo R, Yang P D. (2001). Room-temperature ultraviolet nanowire nanolasers. Science.292:1897-1899.

Jung HI, Jeong JH., Lee OM, Park GT, Kim KK, Park HC, Lee SM, Kim YG, Son H. (2010). Influence of glycerol on production and structural-physical properties of cellulose from Acetobacter $s p$. V6 cultured in shake flasks. ;J.Bioresour Technol. May;101(10):3602-8.

Klemm D, Schumann U, Udhardt S, Marsch, Klemm D, Schumann D, Udhardt U, Marsch S. (2001). Bacterial synthesized cellulose - artificial blood vessels for microsurgery. Prog. Polym. Sci. 26, 1561-75.

Koipaei HM, Shareghi B, Saboury AA, Davar F, Semnanie A, Evinic M. (2016). Green synthesis of zinc oxide nanoparticles and their effect on the stability and activity of proteinase K. RSC Adv. 6: 42313-42323.

Law M, Greene LE, Johnson JC, Saykally R, Yang,P D.(2005). Nanowire dye-sensitized solar cells. Nat. Mater. 4: 455-459.

Levy-Clement C, Tena-Zaera R, Ryan MA, Katty A, Hodes G. (2005). CdSe-sensitized p-CuSCN/nanowire n-ZnO hetero junctions. Adv. Mater. 17: 1512-1515.

Li X, Chen S, Hu W,Shi S, Shen w, Zhang X, Wang WH. (2009). In situ synthesis of CdS nanoparticles on bacterial cellulose nanofibers; Carbohydrate Polymers .2009,76 . 509512.

Look DC. (2001). Recent advances in $\mathrm{ZnO}$ materials and devices.Mat. Sci. Eng. B-.Adv. 80: 383-387.

Ma Y, Zhou Y, Qi L, Zhang T, Wang W, Zhang D, Zhang X. (2010). Biotemplated Synthesis of Gold NanoparticleBacteria Cellulose Nanofiber Nanocomposites and Their 
Application in Biosensing Adv. Funct. Mater., Adv. Funct. Mater. 20: 1152-1160.

Miao L, Tanemura S, Toh S, Kaneko K, Tanemura M. (2004). Fabrication, characterization and Raman study of anatase- $\mathrm{TiO}_{2}$ nanorods by a heating-sol-gel template process . J. Cryst. Growth. 264: 246-53.

Ozgur U, Alivov YI, Liu C, Teke A, Reshchikov MA, Dogan S, Avrutin V, Cho S J, Morkoc H. (2005). Acomprehensive review of $\mathrm{ZnO}$ materials and devices. J.Appl. Phys. 98: 301-308. Pan ZW, Dai .ZR, Wang ZL. (2001). Nanobelts of semiconducting oxides"Science, 291: 1947-1949.

Park W I, Yi GC. (2004). Electroluminescence in $\mathrm{n}-\mathrm{ZnO}$ nanorod arrays vertically grown on $\mathrm{p}-\mathrm{GaN}$. Adv. Mater. 16 : 87-90.

Patterson AL. (1939). The Scherrer formula for Xray particle size determination. Phys rev. 56: 978-982.

Premanathan M, Karthikeyan K, Jeyasubramanian K, Manivannan G. (2011). Selective toxicity of $\mathrm{ZnO}$ nanoparticles toward Gram positive bacteria and cancer cells by apoptosis through lipid peroxidation. Nanomedicine.7:184-192.

Que D. (2005). Controllable growth of $\mathrm{ZnO}$ nanostructures by citric acid assisted hydrothermal process. Mater. Lett. $59: 1696$. Ross P, Mayer R., Benziman M. (1991). Cellulose biosynthesis and function in bacteria. Microbiol Rev; 55:3 5-58. Schramm M, Hestrin S. (1954). Synthesis of cellulose by acetobacter xylinum . j. gen . Microbiol .11,123,345-352.

Sirelkhatim A, Mahmud S, Seeni A, Kaus NHM, Ann LC, Bakhori SKMB, Hasan H, Mohamed D. (2015). Review on Zinc Oxide Nanoparticles: Antibacterial Activity and Toxicity Mechanism. Review.Nano-Micro Lett. 3: 219-242.

Slusaraka BS, Presler S, Danielewicz D.(2008). Characteristics of bacterial cellulose obtained in Acetobakter xylinum culture for application in papermaking, Fibres Text. East Eur. 4:108-116.

Su B, Wang.K, Dong N, Mu HM, Lei ZQ, Tong Y, Bai J. (2009). Biomorphic synthesis of long $\mathrm{ZnO}$ hollow fibers with porous walls, J. Mater .Process . Technol. 209: 4088-4092.
Svenssona BE, Nicklasson CT, Harraha B, Panilaitisa DL, Kaplana M, Brittbergc P. (2005). Gatenholmb .Bacterial cellulose as a potential scaffold for tissue engineering of cartilage Biomaterials 26: 419-425.

Wang J, Deng X, Zhang F, Chen D, Ding W. (2014). ZnO nanoparticle-induced oxidative stress triggers apoptosis by activating JNK signaling pathway in cultured primary astrocytes. Nanoscale Research Letters. 9: 117-123.

Wang WZ, Zeng BQ, Yang J, Poudel B, Huang JY, Naughton M J , Ren ZF. (2006). Aligned ultralong ZnO nanobelts and their enhanced field emission. Adv. Mater.,18: 3275-3278.

Wang ZL.(2008). Splendid one-dimensional nanostructures of zinc oxide: A new nanomaterial family for anotechnology.ACS Nano. 2:1987-1992.

Wang ZL, Song JH. (2006). Piezoelectric nanogenerators based on zinc oxide nanowire arrays. Science.312, 242-246. Wei TY, Yeh P, Lu SY, Wang ZL. (2009). Gigantic enhancement in sensitivity using Schottky contacted nanowire nanosensor. J. Am. Chem. Soc.131:17690-17695.

Wei YG, Xu C, Xu S, Li C, Wu WZ, Wang ZL. (2010). Planar waveguide-nanowire integrated three-dimensional dyesensitized solar cells. Nano Lett. 10: 2092-2096.

Whang D, Jin S, Wu Y, Lieber CM. (2003). Large-scale hierarchical organization of nanowire arrays for integrated nanosystems Nano Lett. 3: 1255 .

Yeh PH, Li Z, Wang Z. (2009). Schottky-gated probe-free $\mathrm{ZnO}$ nanowire biosensor. Adv. Mater. 21: 4975-4978.

Yi GC, Wang CR, Park WI. (2005). $\mathrm{ZnO}$ nanorods: Synthesis,characterization and applications. Semicond. Sci. echnol. 20: S22-S34.

Zhang Y, Ram KM, Stefanakos EK, Goswami Y D. (2012).

Synthesis, Characterization, and Applications of $\mathrm{ZnO}$

Nanowires. Journal of Nanomaterials. Review, 22: 520- 28. 